\title{
Relationship between Mother's Knowledge of Breastfeeding and Exclusive Breastfeeding for Nursing Mothers in the Operational Area of the Sudiang Primary Health Center
}

\author{
Dian Wahyuni $^{1 *}$, Rosdianah $^{2}$, Asriani $^{3}$ \\ ${ }^{1}$ Medicine Education Study Program, Faculty of Medicine and Health Sciences, Alauddin State Islamic \\ University, Makassar, Indonesia \\ ${ }^{2}$ Department of Anatomy, Faculty of Medicine and Health Sciences, Alauddin State Islamic University, \\ Makassar, Indonesia \\ ${ }^{3}$ Department of Physiology, Faculty of Medicine and Health Sciences, Alauddin State Islamic University, \\ Makassar, Indonesia \\ *Corresponding Author. E-mail: dian22wahyuni@gmail.com, Mobile number: +6282240811429
}

\begin{abstract}
Introduction: Exclusive breastfeeding is breastfeeding only in the first six months without drinks or other additional foods. Several factors influence breastfeeding behavior, one of which is the mother's knowledge. This research was conducted to determine whether there is a relationship between maternal knowledge and exclusive breastfeeding behavior

Methods: The study used an analytic observational study design with a cross-sectional approach. The research sample was breastfeeding mothers who have children aged 6-24 months in the operational area of Sudiang Primary Health Center. Samples were taken using purposive sampling technique with a total sample of 262 people. Data was collected by filling out questionnaires by respondents.

Results: Results showed that mothers with high knowledge and provide exclusive breastfeeding were more than $56.1 \%$. Analysis of the two variables shows the value of $p=0.000$. Statistically, there is a significant relationship between maternal knowledge and exclusive breastfeeding behavior.

Conclusion: Base on the research, it may be concluded that there is a relationship between maternal knowledge and the behavior of exclusive breastfeeding in the operational area of the Sudiang Primary Health Center.
\end{abstract}

Keywords: Maternal Knowledge; Breastfeeding; Exclusive Breastfeeding

Article history:

Received: 12 February2021

Accepted: 26 April 2021

Published: 30 April 2021

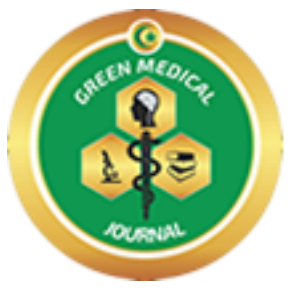

Published by:

Faculty of Medicine

Universitas Muslim Indonesia

Mobile number:

+6282197210007

\section{GREEN MEDICAL JOURNAL \\ E-ISSN 2686-6668}

Publisher: Faculty of Medicine Universitas Muslim Indonesia

Address:

J1. Urip Sumoharjo Km. 5, Makassar

South Sulawesi, Indonesia

Email:

greenmedicaljournal@umi.ac.id 


\section{Introduction}

Breast milk (BM) is a mixture of protein and fat in a carbohydrate-mineral solution. Breastfeeding mothers can quickly produce $600 \mathrm{ml}$ of milk every day, where the quality or quantity of breast milk is not affected by a woman's weight during pregnancy. ${ }^{3}$

Exclusive breast milk (BM) is the provision of breast milk only to babies in the first 6 months of birth without fluids or other solid foods and even water except for oral rehydration solutions, or syrups/drops of vitamins, minerals or medicines. ${ }^{17}$

Importance of breastfeeding babies can be explained scientifically as the Holy Qu'ran also describes the instructions to give breast milk to children. This is explained in the Al Baqarah / 2: 233.

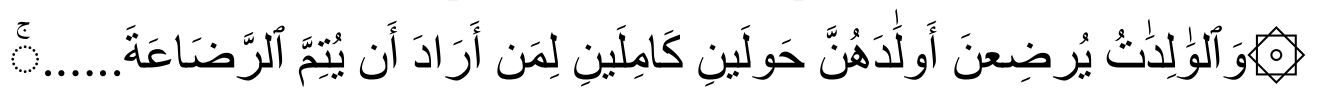

Translation: "Mothers should breastfeed their children for two full years, that is, for those who want to complete breastfeeding ...."4

This verse fragment explains that the best food for babies is breast milk until they are two years old. From birth, mothers are instructed to breastfeed up to two full years of age for those who wish to complete breastfeeding for their children. Two years is not an obligation even though it is ordered, but a strongly emphasized recommendation is to be carried out, as if this is an obligatory order. ${ }^{15}$

Data from the Basic Health Research (Riskesdas) in 2018 shows that the percentage of babies in Indonesia who receive exclusive breastfeeding is still very alarming, namely $37.3 \%$. This confirms that there is still a lack of exclusive breastfeeding in the first 6 months where the success target of exclusive breastfeeding set by the Ministry of Health is $80 \%$. The percentage of exclusive breastfeeding in South Sulawesi has increased and, also, decreased from year to year. In 2011, exclusive breastfeeding coverage was $41.32 \%$, then increased in 2012 by $62.70 \%$ and decreased again in 2014 by $56.31 \%$. The number of babies who were exclusively breastfed in 2015 in the city of Makassar with 43 Primary health centers showed the percentage of babies breastfed for up to 6 months was only $72.43 \% .^{8,16}$

Several Health Center operational areas in the city of Makassar showed success rates of exclusive breastfeeding under the national standard. Where the Health Center with the lowest percentage of success was the Sudiang Primary Health Center with a percentage of exclusive breastfeeding of 27.39\% (192 of 701

babies aged 0-6 months) while the highest success was the Dahlia Health Center with 96.7\% (239 of 248 babies aged 0-6 months). ${ }^{5}$ Based on this data, the percentage of exclusive breastfeeding at Sudiang Primary Health Center is far below the national target. This is what underlies the current study to determine the cause of the low level of exclusive breastfeeding in the operational area of the Sudiang Primary Health Center.

Exclusive breastfeeding is the best food source for babies. However, several obstacles can hinder the process, including low knowledge of mothers about the breastfeeding's benefits for babies and correct 
methods of lactation, less milk production, on the first day of birth the baby is already getting prelacteal feeding (sugar water / formula), nipple abnormalities in mothers, babies having difficulty sucking, pregnant women again while still breastfeeding their babies, having to leave babies at home because mothers go to work, the need to be perceived as modern people, and the influence of incessant advertisements for formula milk. $^{12}$

Knowledge level is affected by age, education and occupation. When viewed from a quality perspective of human resources, education problem in Indonesia is still very far from being compared to other countries. World Education Ranking data published by the Organization for Economic Cooperation and Development (OECD), which outlines the position of a country in terms of education, showed that Indonesia ranks 69 th out of 75 countries. ${ }^{11}$ Based on the data obtained, the level of education in Indonesia is still deficient, this is the basis for this study to determine whether there is a relationship between maternal knowledge about breastfeeding and exclusive breastfeeding for breastfeeding mothers who have children aged 6-24 months in the operational area of the Sudiang Primary Health Center.

Breastfeeding does not only have a positive impact on the baby but also on the mother. Breast milk is the best source of nutrition for the baby's growth and development process. Apart from being a nutrient, breast milk also plays a role in protecting babies from various diseases caused by infection, enhancing the immune system, increasing intelligence, and reducing the incidence of diarrhea in infants. Apart from it benefits for the baby, breastfeeding is also beneficial for the mother, such as strengthening the bond between the child and the mother, improving uterine contractions, and being a natural family planning for the mother/giving distance subsequent pregnancy. ${ }^{13}$

Based on the description above, the current study aimed to determine the knowledge level of breastfeeding mothers regarding the content, benefits, methods of giving and duration of breastfeeding, the success rate of exclusive breastfeeding, and the relationship between maternal knowledge and exclusive breastfeeding. The novelty of this study is a study using a sample of 6-24 months of age, because it has passed the entire breastfeeding period so that the related results are more accurate or not exclusive breastfeeding. Besides, this study uses a larger sample than previous studies.

\section{Methods}

This research is quantitative research using the non-random sampling technique purposive sampling type. This research was conducted in the operational area of the Sudiang Primary Health Center, Biringkanaya District, Makassar City, in January 2020. The sample used in this study was 262 respondents. In this case, the selected sample meets the criteria determined by the researcher. There are two categories of criteria, namely inclusion and exclusion criteria. Inclusion criteria are respondents who have babies aged 624 months, mothers who live with their children, and respondents who live in the working area of the 
Sudiang Primary Health Center. At the same time, the Exclusion Criteria are mothers who do not breastfeed for medical reasons or illness, such as mothers suffering from infectious diseases (HIV / AIDS, tuberculosis, hepatitis B), anatomical abnormalities (inverted nipple), children who have congenital abnormalities such as labioschisis or palatoschisis.

Data used in this study are primary data. Primary data was obtained through direct data collection in the operational area of the Sudiang Primary Health Center. The data analysis used bivariate analysis. Hypothesis testing was completed by the chi-square test method to determine whether there is a relationship between the dependent variable and the independent variable at the 95\% confidence level.

\section{Result}

Table 1 Frequency Distribution of Respondent Characteristics based on Mother's Age, Mother's Education, Mother's Occupation, and Age of Babies in the Operational Area of the Sudiang Primary Health Center in 2020

\begin{tabular}{|c|c|c|c|}
\hline \multicolumn{2}{|c|}{ Characteristics } & Frequency & Percentage (\%) \\
\hline \multirow{5}{*}{ Mother's Age } & $12-16$ years old & 1 & 0.4 \\
\hline & $17-25$ years old & 120 & 45.8 \\
\hline & $26-35$ years old & 118 & 45.0 \\
\hline & $36-45$ years old & 20 & 7.6 \\
\hline & $46-55$ years old & 3 & 1.1 \\
\hline \multirow{4}{*}{$\begin{array}{l}\text { Mother's } \\
\text { Education }\end{array}$} & Elementary (SD) & 36 & 13.7 \\
\hline & Junior high (SMP) & 68 & 26.0 \\
\hline & Senior high (SMA) & 116 & 44.3 \\
\hline & Academy/S1 & 42 & 16.0 \\
\hline \multirow{3}{*}{$\begin{array}{c}\text { Mother's } \\
\text { Occupation }\end{array}$} & Housewife & 178 & 67.9 \\
\hline & Self-employed & 68 & 26.0 \\
\hline & Civil Servant & 16 & 6.1 \\
\hline \multirow{3}{*}{ Age of Babies } & $6-12$ months & 159 & 60.7 \\
\hline & $13-18$ months & 54 & 20.6 \\
\hline & $19-24$ months & 49 & 18.7 \\
\hline
\end{tabular}

Table 1 shows that the characteristics of the most of respondents are between 17 and 25 years old, as many as 120 people (45.8\%), senior high school education is 116 people (44.3\%), respondents work as housewives (IRT) as many as 178respondents (67.9\%) and the age of the baby of the most respondents between the ages of 6-12 months were 159 people $(60.7 \%)$.

Table 2 Knowledge Distribution of Breastfeeding Mothers in the Operational Area of the Sudiang Primary Health Center in 2020

\begin{tabular}{|c|c|c|}
\hline Knowledge & Frequency & Percentage (\%) \\
\hline Good & 188 & 71.7 \\
\hline Not good & 78 & 28.3 \\
\hline Total & 262 & 100 \\
\hline
\end{tabular}

Table 2 shows that breastfeeding mothers with a good level of knowledge were 188 people $(71.7 \%)$, and poor level of knowledge were 78 people $(28.3 \%)$. 
Table 3 Distribution of Exclusive Breastfeeding in the Operational Area of the Sudiang Primary Health Center in 2020

\begin{tabular}{ccc}
\hline Exclusive Breastfeeding & Frequency & Percentage (\%) \\
\hline & 159 & 60.7 \\
\hline Total & 103 & 39.3 \\
\hline
\end{tabular}

From the table above, it can be seen that 159 breastfeeding mothers conduct exclusive breastfeeding (60.7\%) while 103 people do not give exclusive breastfeeding (39.3\%).

Table 4 Results of Mother's Knowledge Relationship Test with Exclusive Breastfeeding in the Sudiang Primary Health Center Operational Area in 2020

\begin{tabular}{cccccccc}
\hline & \multicolumn{6}{c}{ Breastfeeding } & \multirow{2}{*}{ P-Value } \\
\cline { 2 - 7 } Mother's & \multicolumn{2}{c}{ Exclusive } & \multicolumn{2}{c}{ Non-Exclusive } & \multicolumn{2}{c}{ Total } & \\
\cline { 2 - 7 } Knowledge & $\sum$ & $\mathbf{\%}$ & $\sum$ & $\mathbf{\%}$ & $\sum$ & $\mathbf{\%}$ & \\
\hline Good & 147 & 56.1 & 41 & 15.6 & 188 & 71.7 & \multirow{2}{*}{$\mathbf{0 0 0}$} \\
\hline Not Good & 12 & 4.6 & 62 & 23.7 & 74 & 28.3 & \\
\hline Total & $\mathbf{1 5 9}$ & $\mathbf{8 0 . 1}$ & $\mathbf{1 0 3}$ & $\mathbf{1 9 . 9}$ & $\mathbf{2 6 2}$ & $\mathbf{1 0 0}$ & \\
\hline
\end{tabular}

Table 4 shows that respondents with good knowledge and conduct exclusive breastfeeding to babies were 147 people $(56.1 \%)$ and respondents with good knowledge but do not conduct exclusive breastfeeding to babies were 41 people (15.6\%). Meanwhile, respondents with poor knowledge but who were exclusively breastfeeding their babies were 12 people (4.6\%), and respondents with poor knowledge and did not conduct exclusive breastfeeding for babies were $62(23.7 \%)$.

Results of statistical tests by Chi-square on the variables of mother's knowledge about breastfeeding and the variable of exclusive breastfeeding, using $p$-value of $0.000(<0.05)$ indicated that $\mathrm{H}_{0}$ was rejected / $\mathrm{H}_{1}$ was accepted, which means that there was a significant relationship between mother's knowledge on breastfeeding and exclusive breastfeed in the operational area of the Sudiang Primary Health Center. The following chart provides more details:

Graph 1 Test Results of Mother's Knowledge Relationship with Exclusive Breastfeeding

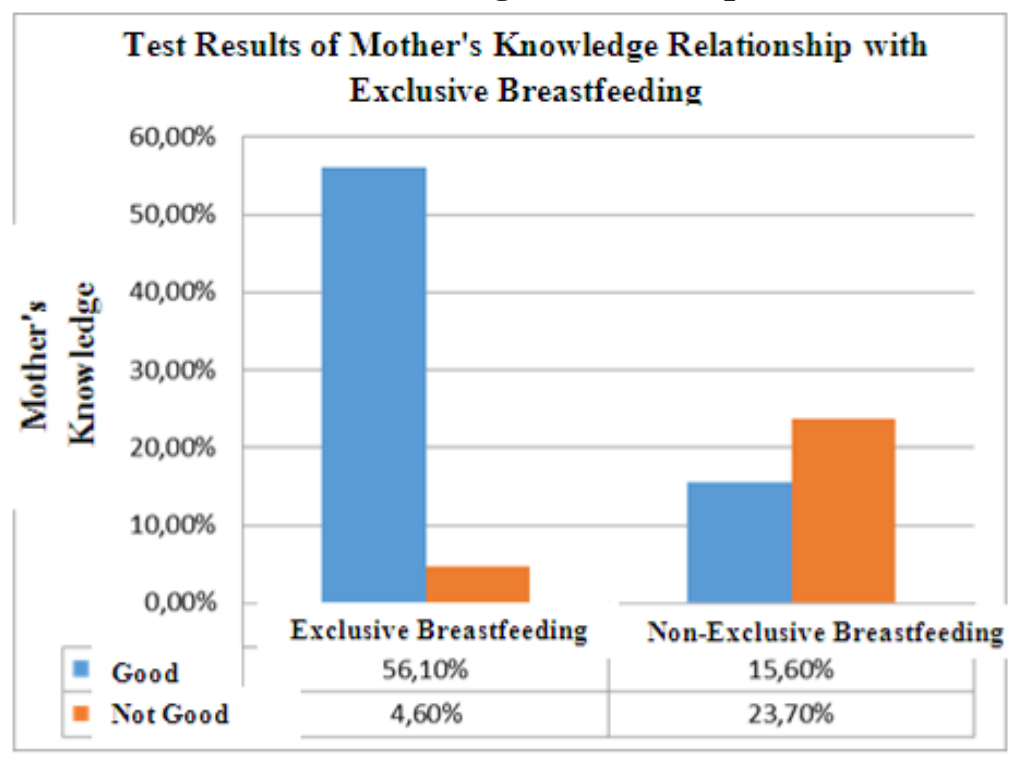




\section{Discussion}

This study was conducted by measuring the level of mother's knowledge on the breastfeeding based on exclusive breastfeeding application to 262 mothers. Results showed that mothers with good knowledge were 188 mothers $(71 \%)$, where 147 mothers (56.1\%) gave exclusive breastfeeding and 41 mothers $(15.6 \%)$ did not exclusively breastfeed their children. Meanwhile, 78 mothers $(28.2 \%)$ had poor knowledge, where 12 mothers (4.6\%) gave exclusive breastfeeding and 62 mothers (23.7\%) did not exclusively breastfeed their children.

Based on this study, it can be proven that the level of knowledge of mothers about breastfeeding affects the act of exclusive breastfeeding. According to Budiman (2016), several factors several factors influence, among others, education, information obtained from social media, culture and economy, environment, individual experience, and age. Education is used to obtain the information to improve the quality of life by being considered a human guide to act and fill life. ${ }^{6}$

Knowledge has a significant role in determining mother's behavior as knowledge will bring understanding to the mother about the good and bad effects of exclusive breastfeeding. This understanding will be the basis for mothers to behave in giving exclusive breastfeeding for their babies. ${ }^{10}$

The study results showed that the characteristics of respondents based on age indicated that most of the respondents were aged 17-25 years at $45.8 \%$ and ages 26-35 years at 45.0\%. Regarding knowledge, mothers with this age range can be said to have the ability to digest various information obtained to increase their understanding of exclusive breastfeeding. The construction of mother's knowledge is also affected by the level of education. Results of the analysis on the characteristics of the research respondents revealed that the majority of respondents with high school education were $44.3 \%$. A mother's education level affects the formation of a mindset that is open to new things. The more information the mother obtains, the better her level of knowledge. A person who has more information will have more knowledge too. ${ }^{12}$ Based on Nainggolan (2016) research, education affects maternal knowledge, where a well-informed mother is a mother who is highly educated in the health sector, a more educated mother will encourage someone to seek more information about the things they experience.

Based on the results, it is showed that exclusive breastfeeding in the operational area of the Sudiang Primary Health Center was $60.7 \%$. The result means that the majority of respondents have exclusively breastfed their babies but the percentage of this figure is still below the national target of $80 \%$. Exclusive breastfeeding only provides breast milk to the baby and not given any other drinks or foods. Meanwhile, the respondents who did not exclusively breastfeed were 39.3\%, namely 103 people.

Breast milk as natural food is the best food that mothers can provide to their newborn children so that they do not need additional food because all nutritional needs can be met from breast milk to ensure growth and development until the age of 6 months. Also, babies under six months of age have perfect digestive 
enzymes that are not yet perfect, so they cannot digest food properly. Judging from the education level of the respondents, it is known that most of them have high school education at $44.3 \%$. Higher levels of education will increase awareness of better health. Mothers with higher education already have a good mindset that is formed from the formal education process they go through so that it can influence behavior, one of which is manifested in exclusive breastfeeding. ${ }^{9,14}$

Exclusive breastfeeding has excellent benefits for babies, which can improve the baby's immune system and improve the baby's immune system and increase intelligence and increase the relationship between mother and baby. ${ }^{16}$

Table 4 shows a statistically significant relationship $(p<0.05)$ between knowledge and exclusive breastfeeding by mothers who have babies aged 6-24 months in the operational area of the Sudiang Primary Health Center. With this, the hypothesis in this study proved that there was a relationship between knowledge and behavior of exclusive breastfeeding by mothers who have babies aged 6-24 months. These results may imply that expertise contributes significantly to the formation of complete breastfeeding practices. The results obtained in this study are in line with the theory which states that one's cognitive or knowledge is a factor that plays an essential role in shaping one's actions / behavior. From research and experience, it is proven that behavior based on knowledge shall be more durable when compared to behavior that is not based on knowledges. ${ }^{10}$

The study results are in line with the results of research conducted by Dian Aviyanti et al. entitled "The Relationship of Mother Education and Knowledge about Exclusive Breastfeeding and Attitudes Toward Exclusive Breastfeeding in 2012," which used 30 samples of breastfeeding mothers with children aged 0-6 months where the study results showed that there was a relationship between mother's knowledge and the attitude of exclusive breastfeeding. ${ }^{2}$

The importance of science is seen from its benefits, but as a Muslim, studying is an obligation that must be done, both for men and women. This is explained in the hadith of Sunan Ibn Majah No.220:

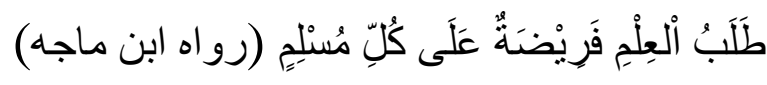

Translation: "Demanding knowledge is an obligation for every individual Muslim" This hadith narrated by Ibn Majah explains that knowledge is essential for humans in the life of the world and the hereafter. Humans will not be able to live this life without knowing. Even what makes humans have advantages among other God's creatures is because humans have knowledge. ${ }^{7}$ This hadith shows the similar meaning with the results of this study, wherein this hadith it has been explained that a Muslim's obligation to follow knowledge, if someone is knowledgeable, then he will understand between bad behavior and good behavior. A mother who has a good understanding of breast milk may exclusively breastfeed her child.

Several reasons and cultural factors are inherent in society that support a mother often giving supplementary food to her baby at $<6$ months of age. Mother's behavior to provide exclusive breastfeeding 
will only be formed if a mother has the correct knowledge about exclusive breastfeeding, including the definition, reasons for exclusive breastfeeding, the benefits and effects of not giving exclusive breastfeeding. ${ }^{12}$ The results of this study indicated that the better a mother's level of knowledge, the better the exclusive breastfeeding behavior. Supported by the results of cross-tabulation, it is known that most of the respondents who have good knowledge give exclusive breastfeeding to their babies at $56.1 \%$ and mothers who have poor knowledge and do not give exclusive breastfeeding were $23.7 \%$. This shows that knowledge contributes significantly to exclusive breastfeeding behavior.

The study showed that 41 respondents $(15.6 \%)$ had good knowledge but did not conduct exclusive breastfeeding to the babies and as many as 12 respondents (4.6\%) who had poor knowledge but gave exclusive breastfeeding to their babies. Several factors can affect the behavior of exclusive breastfeeding, including ability, education, mother's health / physical condition, family income, work, and getting support from family, community and the role of health workers to participate in explaining why mothers are about the importance of exclusive breastfeeding to babies. ${ }^{1}$

Based on the description above, mothers with good knowledge of exclusive breastfeeding pay better attention to the importance of exclusive breastfeeding for their babies and themselves. Thus, mothers with good knowledge apply more efforts into giving exclusive breastfeeding to their babies.

\section{Conclusion}

Research results lead to the conclusion that the level of knowledge of mothers about exclusive breastfeeding in the operational area of the Sudiang Primary Health Center was mostly in the good category, the practice of exclusive breastfeeding in the operational area of the Sudiang Primary Health Center was $60.7 \%$ and there was a significant relationship between maternal knowledge and giving exclusive breastfeeding in the operational area of the Sudiang Primary Health Center. Results of the ChiSquare analysis obtained a $p$-value of $0.000(\mathrm{p}<0.05)$.

\section{Conflicts of Interest}

No potential conflict of interest relevant to this article was reported.

\section{Funding sources}

None

\section{Acknowledgments}

The author would like to thank all Doctors, Midwives, Puskesmas staff, and Posyandu Cadres at Sudiang Primary Health Center for their willingness to be involved in the research. The author also thanks 
the Supervisors who have provided guidance and direction during this research.

\section{References}

1. Agustina, T. A. (2015). Eksklusif Di Desa Dukuhwaru Wilayah Kerja Puskesmas Dukuhwaru Kabupaten Tegal Tahun 2015. Politeknik Harapan Bersama, 123-125.

2. Widiyanto, S., Aviyanti, D., \& A, M. T. (2012). Hubungan Pendidikan dan Pengetahuan Ibu tentang ASI Eksklusif dengan Sikap terhadap Pemberian ASI Eksklusif Subur. Jurnal Kedokteran Muhammadiyah, 1(2), 25-29.

3. Cunningham, F. Gary, et al. (2012). William Obstetrics, 23rd Ed Vol 1. Jakarta : EGC

4. Departemen Agama RI. (2005). Al-Qur'an dan Terjemahannya. Bandung : PT. Syamsil Cipta Media

5. Dinas Kesehatan Provinsi Sulawesi Selatan. (2016). Profil Kesehatan Provinsi Sulawesi Selatan Tahun 2015. Makassar : Dinas Kesehatan Provinsi Sulawesi Selatan

6. Firmansyah N., Mahmuda. (2017). Pengaruh Karakteristik (Pendidikan, Pekerjaan),Pengetahuan Dan Sikap Ibu Menyusui Terhadap Pemberian ASI Eksklusif Di Kabupaten Tuban. Jurnal Biometrika dan Kependudukan, Volume 1 Nomor 1, Agustus: 62-7.

7. Ismail, Syuhudi. (2015). Kaidah Kesahihan Sanad Hadis (Telaah Kritis dan Tinjauan dengan Pendekatan Ilmu Sejarah). Jakarta: Bulan Bintang

8. Kementrian Kesehatan Republik Indonesia. (2018). Data Riset Kesehatan Dasar tahun 2018. Jakarta : Kemenkes RI.

9. Nadesul. (2015). Makanan Sehat Untuk Bayi. Jakarta: Puspa Swara

10. Notoadmodjo, Soekidjo. (2016). Pendidikan dan Perilaku Kesehatan. Jakarta: Rineka Cipta.

11. Organisation for Economic Coperation and Development. (2015). PISA Assessment Framework.. Diakses tanggal 10 Oktober 2019. www.oecd.org

12. Partiwi., Ayu Nyoman, Purnawati, Jeanne. (2009). Kendala Pemberian ASI eksklusif dan Cara Mengatasinya. Jakarta : Indonesian Pediatric Society

13. Prawiroharjo, Sarwono. (2010). Ilmu Kebidanan. Jakarta : PT Bina Pustaka

14. Rosita. (2018). ASI Untuk Kecerdasan Bayi. Yogyakarta: Ayyana

15. Shihab, M. Quraish. (2016). Tafsir Al-Mishbah Volume 1. Tangerang : PT. Lentera Hati

16. Suradi, R. (2018). Manfaat ASI dan Menyusui. Jakarta : Balai Penerbit Fakultas Kedokteran Universitas Indonesia

17. World Health Organisation. (kk2019). Exclusive breastfeeding (Accessed 10 Oktober 2019) http://www.who.int/elena/titles/exclusive_breastfeeding/en/ 